\title{
Hjemme best?
}

\author{
Internasjonal medisin er innholdsmessig ingen ny spalte i Tidsskriftet. Selv i 1918 brakte man inntrykk \\ fra den store verden, her vist ved en artikkel fra Kina med illustrerte kasuistikker og ulike betraktninger \\ om et ikke-velfungerende helsevesen (Tidsskr Nor Lægeforen 1918; 38: 560 -73).
}

\section{Oplevelser og iagttagelser i Kina.}

Av Volrath Vogt, missionslæge i Kina.
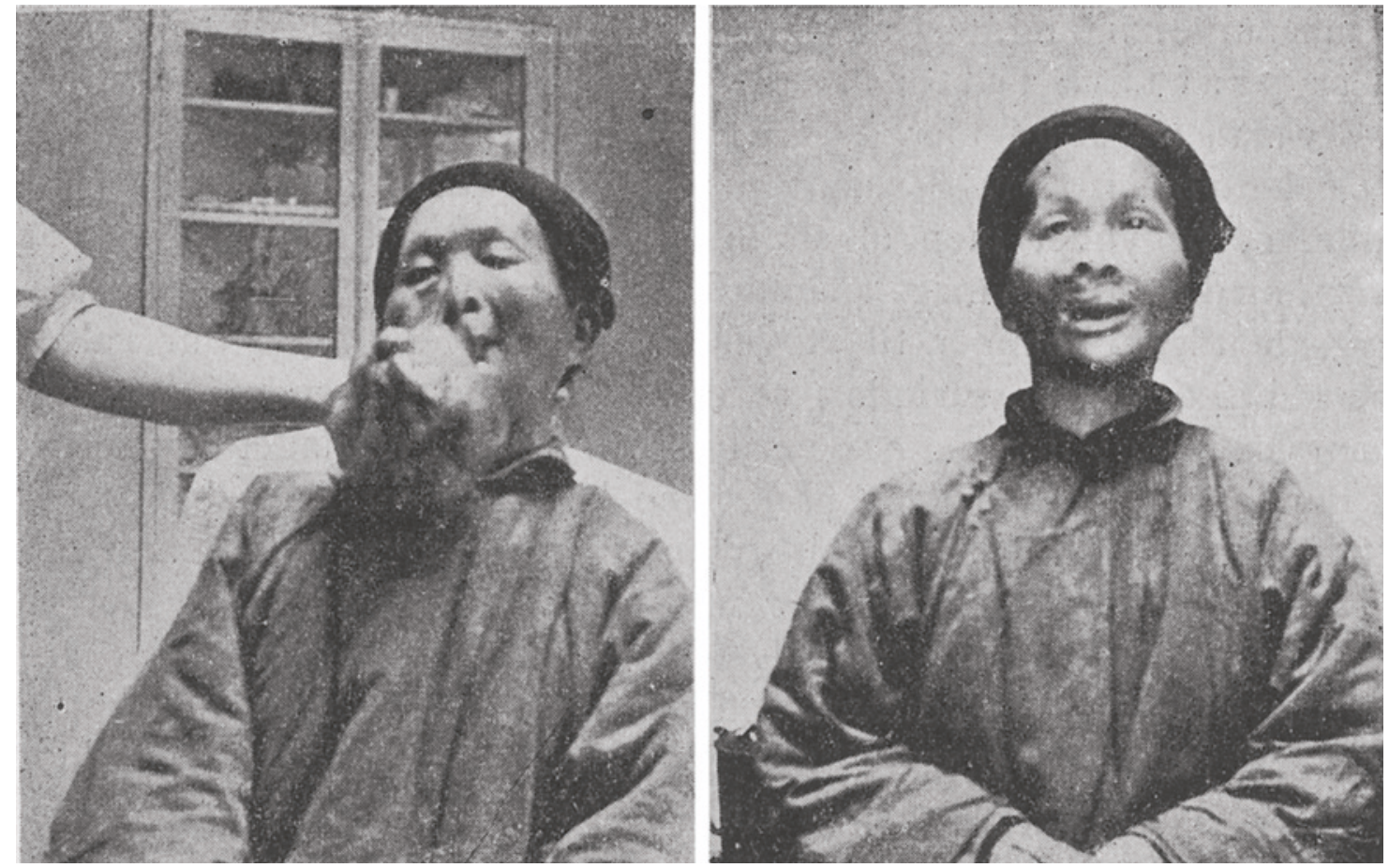

Barnehodestort, stilket fibrom; ca. 8 aars varighet. Blev av kinesiske læger anset for inoperabelt.

Selvmord i de mest barbariske former er meget hyppige. For 6-8 aar siden brukte de for det meste opium, og naar vi bare blev tilkaldt i tide, saa kunde vi ofte redde livet. Paa alle vore stationer var man derfor utstyrt med greier til at foreta maveskylling, og der er i aarenes løp reddet mange menneskeliv ved vore stationer. Men nu er opiumen blit kostbar, - ja, mange steder er den forsvundet; derfor har de grepet til det, som er værre end opium, nemlig salpetersyre eller saltsyre. De kommer først til os efter mange timers eller dages forløp, naar etsningen allerede er en fuldbragt kjendsgjerning; disse patienter faar et yderst smertefuldt sykeleie; de dør gjerne efter et par maaneders forløp. Ellers bruker de baade fosforstikker og forskjellige giftige planter. Hvis man spør, hvorfor de har villet ta livet av sig, saa faar vi gjerne den besked, at der har været en trætte om et beløp paa 10-20 øre; de bruker det nærmest som en hævn over sine fiender, fordi de mener, at deres egen aand ikke vil gi deres motstandere et rolig øieblik mere her i verden. Forøvrig er jo denne tilbøielighet til selvmord et av de mest alvorlige vitnesbyrd om, hvor liten værdi livet har for kineserne. - Kineserne er ilde stillet, naar de blir syke; thi deres lægevæsen er i enhver henseende uskikket til at fylde sin opgave. Blandt alle - selv de mest primitive - folkeslag finder man jo bestræbelser, som har tatt sigte paa at hjælpe de syke, og det samme finder man selvsagt ogsaa hos kineserne; men til trods for den ældgamle kultur staar lægekunsten ganske overordentlig lavt. - (...) 